\title{
INDONESIA ADMINISTRATIVE E-COURT REGULATION TOWARD DIGITALIZATION AND E-GOVERNMENT
}

\author{
Aju Putrijanti \\ Faculty of Law, Diponegoro University \\ ajuputrijanti@lecturer.undip.ac.id \\ Kadek Cahya Susila Wibawa \\ Faculty of Law, Diponegoro University \\ kadekwibawa@lecturer.undip.ac.id
}

\begin{abstract}
E-court regulation in Indonesia legalized in order to follow and adjust the digitalization, modernization and globalization. Administrative Court is judiciary body which has to implement the e-court. The object is to analyse the implementation of e-court towards e-governmnet. The method use to analyze is normative juridical research, study the documents (regulation), and secondary data are journals, opinion from experts. The issues are the implementation of administrative e-court in Indonesia towards the development of e-government. The implementation of administrative e-courtcan not fully implemented because there is legal interpretation in Supreme Court Regulation Number 1 Year 2019 of Case Administration and Court Electronically, there is no regulation of implementation for both process. There is inconsistency between Article number 24 and 25 of Supreme Court Regulation, for evidentiary process follows regulations for each procedural system. The development e-government has shows good effort, whereas it still need to improve. There should be a new regulations to substitute Perma, and to harmonize with the regulations of Administrative Court in future. The implementation of Administrative e-court is absolutely carried out in the digital era. It is to support the realization of e-government.
\end{abstract}

Keywords: e-court; administrative court; digitalization; e-government

\section{INTRODUCTION}

As state law, government has an important role in implementation of government administration for citizen. The implementation of government has to be based on regulations and supervised from internal and external body. As the information technology (IT) become salient, also digitalization, globalization and modernization, makes borderless for some purposes. Government has been used development of IT to supervise, implement, guidance the government's act, this also increase the economy sector while preparing infrastructures for supporting the internet access, serving the public service, giving information from government can be easily and fast.

The central point of Indonesia state of law is harmonization relation between citizen and government based on principle of harmony and become 
the philosophy background of the Administrative Court (hereinafter called Court), because the concept of Indonesia state of law is not similar to rechtsstaat either rule of law ${ }^{1}$. Martin Krygier stated: in all its many versions, the rule of law has to do with the relationship between law and the exercise of power, particularly public power. As an ideal, it signals that law can and does well to contribute to articulating, channeling, constraining, and informing - rather than merely serving - such exercise. ${ }^{2}$ Courts are preeminent information systems and are institutions which process information and translate it into the exercise of power by rendering judgments. ${ }^{3}$

The concept of Indonesia state of law has some different points according to Oemar Seno Adji, Padmo Wahyono, Philipus M. Hadjon, which stated that Pancasila is fundamental philosophy, then principle of harmony, as one value of Pancasila, is using to harmonized between government, public interest, human rights, and against absolutism ${ }^{4}$. Fais Yonas Bo'a stated that Pancasila as the source of all sources of law gives meaning that the national legal system must be based on Pancasila. ${ }^{5}$ The rule of law as stated by A.V. Dicey has meaning i.e, supremacy of law, equality before the law, guarantee of human rights, and F.J. Stahl declare rechtsstaat consist of recognition and protection of human rights, divide and separation of power, government based on regulations and administrative court. Those concept of state of law, formally have same meaning, but substantially they have different meaning based on history and philosohpy of life for each country.

As state of law put the protection of human right's law as primary, mainly guarantee for legal certainty, order and legal protection based on justice and correctness. ${ }^{6}$ Court has to make an external supervision to government, by verifying the dispute object and protection of human rights. The goals of Court are to harmonize rights between the individual or legal entity as a citizen and government officer and / or body, when there is a mistake of decision-making and gives loss to individu or legal entity. As said by W. Riawan Tjandra, the existence of Court in the globalization era are important because to guarantee and reliance to the law, again to protection of rights of citizen. ${ }^{7}$

Administrative Court is specialized court under Supreme Court with absolute competence to investigate and settle the administrative dispute. Court was formed based

\footnotetext{
${ }^{1}$ Maftuh Effendi, 2017, Dinamika Yurisdiksi Peradilan Administrasi, Pusaka Media, Jakarta, pg 21.

${ }^{2}$ Martin Krygier, Rule of Law (and Rechtsstaat)," International Encyclopedia of the Social \& Behavioral Sciences (Second Edition) March (2015): 78-787, https://doi.org/https://doi.org/10.1016/B978-0-08-097086-8.86105-X., accessed on 5 July 2020.

${ }^{3}$ Pinaki Nandan Pattnaik, Satyendra C. Pandey, and Mahendra Kumar Shukla, Mapping Critical Success Factors in Efficient Court Management: Two Case Studies from India, International Journal of Law and Management 60, no. 2 (2018): 717-29, https://doi.org/10.1108/IJLMA-03-2017-0023. accessed on 5 July 2020

${ }^{4}$ Hendrik Salmon, "EKSISTENSI PERADILAN TATA USAHA NEGARA (PTUN) DALAMMEWUJUDKAN SUATU PEMERINTAHAN YANG BAIK Oleh : Hendrik Salmon," Jurnal Sasi 16, no. 4 (2010): 16-26.

${ }^{5}$ Fais Yonas Bo'a, Pancasila Sebagai Sumber Hukum Dalam Sistem Hukum Nasional, Jurnal Konstitusi 15, no. 1 (2018): 27-49, https://doi.org/10.31078/jk1512. accessed on 6 July 2020

${ }^{6}$ Marten Bunga, "Usaha Negara Dalam Menyelesaikan Sengketa Tanah," Gorontalo Law Review 1, no. 1 (2018): $39-49$.

${ }^{7}$ Dani Habibi, "Perbandingan Hukum Peradilan Tata Usaha Negara Dan Verwaltungsrecht Sebagai Perlindungan Hukum Rakyat," Kanun Jurnal Ilmu Hukum 21, no. 1 (2019): 1-22.
} 
on Act No 5 Year 1986 of Administrative Court and had been twice amended by Act Number 9 Year 2004 and Act Number 51 Year 2009, to adjust and based on Indonesia Constitutional 1945 which had been fourth times amendment. The shifting paradigm in administrative law and Court's competence comes after the amendment of Indonesia Constitution 1945, which considering human rights and democracy as mainstream based on liberalism and individualism. ${ }^{8}$ In their research, stated that after Act Number 30 Year 2014 of Governance Administration had been legalized, the Court has broader competence not only specific administrative disputes but more general administrative disputes.

Act Number 30 Year 2014 of Governance Administration brings new paradigm in administrative law and Court, which regulates the government's activities in public sector, as guidance to make decision-making, administrative sanctions, abuse of power, ficititious positive and other related government's act. This development shows that administrative law and Court move to codified administrative law since previously there is no administrative law which regulates clearly and gives legal certainty.

Supreme Court has been enactment Supreme Court Regulation Number 3 Year 2018 concerning Electronic Case Administration, showed the will and support to government in implementation of e-government. Sudarsono stated that Supreme Court Regulation Number 3 Year 2018 concerning Electronic Case Administration only regulates the procedure that might be held electronically, without contradicting the procedural law in Act Number 5 Year 1986 of Administrative Court, such as dismissal process, preparatory examination and announcement of judge verdict ${ }^{9}$. This regulations amended by Supreme Court Regulation (hereinafter is Perma) Number 1 Year 2019 of Case Administration and Court Electronically, and make regulations more complete with some revisions, but there are still legal gaps in some articles and can caused uncleared for implementation. E-court is a new style of judiciary system using IT, but there are some important points can not be abandon, and keep remain in the judiciary system for each type of court. Some special procedures and principles has to implement because it is a part of whole judiciary system of each court. Government has to socialize about these new style of court to public, besides to know the reaction from public about the implementation and regulation.

The primary research question is the legal gap in the implementation of e-court focus in administrative court and to development the e-government. The urgency of implementing administrative e-courts in Indonesia. The result of this study have

\footnotetext{
${ }^{8}$ et.al Phahlevy, Rifqy Ridlo, "Pergeseran Paradigma Peradilan Tata Usaha Negara Di Indonesia Dan Belanda," Arena Hukum 12, no. 3 (2019): 576-91.

${ }^{9}$ Sudarsono, 2019, Penerapan Peradilan Elektronik Di Lingkungan Peradilan Tata Usaha Negara, in Legal Issues Pada Peradilan Tata Usaha Negara Pasca-Reformasi Hukum Acara Dan Peradilan Elektronik, Kencana, Jakarta, pg. $182-221$.
} 
implication of the e-court particular in administrative court and development of e-government.

This research use normative legal (doctrinal law) research. Doctrinal law research uses a regulatory (statute) approach. ${ }^{10}$ Related. The primary data used are regulations, and for secondary data are journals, opinion from experts, the research results. The regulations should collected and divided to find out the relevant with the issues, either the judge verdicts. ${ }^{11}$

\section{DISCUSSION}

\section{Implementation of e-Court in Indonesia Administrative Court}

Digitalization is supported by new information and communication technologies (ICTs) embracing systems such as virtualization mobility and analytical systems, promising to revolutionize the way business is conducted within industrial value chains through the use of Internet of things (IoT), technologies, intensive data exchange and predictive analytics. ${ }^{12}$ The digitalization has brought new perspective in government, especially using the internet to connect easily and give fast information to the citizen. The conventional style of government has reduced slowly, however it still applied for some reasons in government offices. This refers to administrative procedures in all sector, when people can submit application by filling from anywhere to the government offices, all the offices are connected and integrated, it makes easier to govern. This

\footnotetext{
${ }^{10}$ Kadek Cahya Susila Wibawa and Sri Nurhari Susanto, "Establishing a Special Autonomy Model in Bali as a Means of Preserving Hindu Balinese Culture and Space," International Journal of Scientific and Technology Research 9, no. 4 (2020): 1609-14, http://www.ijstr.org/final-print/apr2020/Establishing-A-Special-Autonomy-ModelIn-Bali-As-A-Means-Of-Preserving-Hindu-Balinese-Culture-And-Space.pdf.globalization, and tourists visiting Bali. On other hand, in the last five years, Bali has contributed about $40 \%$ of foreign exchange tourism to Indonesia, but ironically Bali does not get funds for foreign exchange earnings. The development of cultural tourism in Bali requires a comprehensive management and requires no small amount of funds. Bali needs special authority to manage the government in Bali with the uniqueness of the region, the situation, and the potential it has in order to support cultural preservation and guarantee sustainable development in Bali. This research aims to build an ideal special autonomy model as an effort to preserve culture in Bali. Based on these objectives, this study combines doctrinal research and non-doctrinal research. Doctrinal research uses a philosophical, conceptual, and regulatory approach. Non-doctrinal legal research, this research relies on the constructivism paradigm. The special autonomy of Bali is very much needed by the Balinese people to guarantee the strengthening of Hinduism, cultural preservation, customs and local traditions in Bali, because these are the main points in the development of cultural tourism in Bali. The ideal Balinese special autonomy model at the moment is based on its philosophical foundation based on local cultural wisdoms of $\backslash$ "tri hita karana \" and \"sad kerthi〉", but still within the corridor of the Republic of Indonesia. Another construction is the distribution of profit sharing funds from the tourism sector and its management with the concept of $\backslash$ "one province, one island, and one management system \",","author":[\{“dropping-particle":"”,",family":"Wibawa","given":"Kadek Cahya Susila","non-dropping-particle":",,"parse-names":false,"suffix":"”\},\{“dropping-particle":"”,"family":"Susanto","given":"Sri Nurhari","non-dropping-particle":",",parse-names":false,"suffix":"”\}],"container-title":"International Journal of Scientific and Technology Research","id":"ITEM-1","issue":"4","issued":\{ “date-parts":[[“2020 "l]\},"page":"1609-1614","title":"Establishing a special autonomy model in Bali as a means of preserving hindu balinese culture and space","type":"article-journal","volume":"9" \},"uris":[“http://www.mendeley.com/documents/?u uid = 34c833ed-8060-4aa2-81fe-9aec3fbd860b"]\}],"mendeley": “formattedCitation":"Kadek Cahya Susila Wibawa and Sri Nurhari Susanto, "Establishing a Special Autonomy Model in Bali as a Means of Preserving Hindu Balinese Culture and Space," < i > International Journal of Scientific and Technology Research </i > 9, no. 4 (2020 accessed on 10 July 2020

${ }^{11}$ Aju Putrijanti and Kadek Cahya Susila Wibawa, "The Role of Administrative Court in Reinforcing the Good Governance," Test Engineering and Management 83, no. March-April (2020): 18483-89, http://testmagzine.biz/ index.php/testmagzine/article/view/6980/5388. accessed on 10 July 2020

${ }^{12}$ Rossella Canestrino et al., "The Digitalization in EMAS-Registered Organizations: Evidences from Italy and Poland," TQM Journal, 2020, https://doi.org/10.1108/TQM-12-2019-0301. accessed on 17 July 2020
} 
system needs a proper, administrative regulation to support sharing information and collaboration in e-government era. ${ }^{13}$ It is duty of government to provide and support of the implementation of modernization in judiciary system, especially for those who seek for justice.

Implementation of IT will give benefits such as speedy, precision, reliability which directly proportional to principle of judiciary as simple, low cost and speedy, on the other hand Dory Reiling said there are some classical problems such as delay of trials, difficult to access and integrity. ${ }^{14}$ The development of IT relates with court and justice system, raise artificially intelligent (AI) justice and change the rules and values, develop artificial intelligent adjudication. Richard M. Re and Alicia Solow-Neiderman said “... AI adjudication will tend forces toward greater measure-ability, objectivity and empiric in the legal system". ${ }^{15}$ The trend of using AI can be seen in using and implementation of IT in judiciary system, starting from the register the application to the Court, the process of judiciary system, interpretation of regulations including the judge verdict. The regulations as substance of law also has important role besides the structure of law to support the AI adjudication for the development of legal system.

Legal profession should increase their capability in public trust especially in legal system and human element of legal work by develop their knowledge of technology that can be used to regulate society, and the need of legal profession to communicate clearly, show professional ethic and increase competence to deal with multi-perspective, open endedness an ambiguity of social-conflicts. ${ }^{16}$ It is necessary for legal profession to have ability in AI adjudication with develop their professional ethic become more aware due to the changes of society behavior may occur. The expertise of IT will assure the client, while they depend on the legal profession to fight in the court, then it will develop code of conduct of legal profession in the digital era.

E-court meaning as the process to investigate and adjudicate the disputes by the court supported by information and communication technology. Moving from conventional court to modern future court based upon information technology and re-conceptualized some important principles in each state legal system. ${ }^{17}$ This new concept of court can been seen as a part of good governance in a broad scope. Tonn et.al, also define good governance from perspective of court, meaning that court should be a flexible, convergence to solve the disputes, fair justice and easy to get access to justice. This perspective is important to upgrade the court's performance and improve their system.

\footnotetext{
${ }^{13}$ Yu-che Chen et al., "Cross-Boundary e-Government Systems : Determinants of Performance," Government Information Quarterly 36, no. 3 (2019): 449-59,https://doi.org/10.1016/j.giq.2019.02.001. accessed on 17 July 2020

${ }^{14}$ Asep Nursobah, "Pemanfaatan Teknologi Informasi Untuk Mendorong Percepatan Penyelesaian Perkara Di Mahkamah Agung," Jurnal Hukum Dan Peradilan 4, no. 2 (2015): 323-34.

${ }^{15}$ Richard M Re and Alicia Solow-niederman, "Developing Artificially Intelligent Justice," Stanford Technology Law Reviewd Technology Law Review 22, no. 8 (2019): 242-89.

${ }^{16}$ Werner Schäfke-zell and Ida Helene Asmussen, "The Legal Profession in the Age of Digitalisation An Outline of Three Potential Transformations in Legal Education," Utrecht Law Review 15 (2019): 65-79.

${ }^{17}$ Bruce Tonn et al., "Future of the Courts : Fixed, Flexible, and Improvisational Frameworks," Futures 44, no. 9 (2012): 802-11, https://doi.org/10.1016/j.futures.2012.07.005. accessed on 1 August 2020
} 
The capability of using and understanding IT for legal profession is important, they have to read, understand and implement the regulations.

Refer to Sudarsono, implementation Court become e-court needs be a new regulation, though his argument based on Perma Number 3 Year 2018 as the first regulation of court administration electronically, or as pioneer to become an e-court ${ }^{18}$. Previously, in Perma Number 3Year 2018 regulates the court administration, consist of registration, the subpoena electronically and court's management using internet. The new regulation in Perma has been improve as guidance for court administration and e-court. Some articles have been added to revise the previous regulations, but still needs legal interpretation to learn and understand carefully. The articles which has been added, mostly regulates about the procedural law. Legal profession has to aware, rigorous, carefully if they will submit the lawsuit to the Court, since the regulations can make different legal interpretation.

The implementation of e-court based on Perma can be implemented into general court for civil cases, religious court, military court and administrative court. Supreme Court has divided into 4 (four) steps, i.e.: e-filling, e-payment, e-summons and e-litigation, while this valid for all the courts as regulates. First, e-filing as the beginning point to fulfill the lawsuit to the court. Fill in the lawsuit has to follow the regulations for each court. Second, e-payment means that the Plaintiff has to pay imprest at the bank, for further step. Third, e-summons is court information and asked all the parties to come online for the court. Fourth, e-litigation is process to adjudicate using the information and communication technology as provided. All the process should prior to independence of judiciary as universal principles.

To fill in the lawsuit to the Court, can be done by registered user is registered lawyer to Supreme Court, and other registered as legal subject other than lawyer, such as government law office, in-house lawyer, incidental lawyer, legal department in government office/military/police. The object of disputes are based on Act Number 5 Year 1986 of Administrative Court and its amendments, is the government's decree. After the complete process of e-filling, than the Plaintiff can pay the imprest based on e-payment to the bank.

The Court will give the register number in working days after e-payment complete, then the e-court application will give notification that the case already registered. Next step is e-summons; the parties will receive the subpoena through e-mail of registered user and can be seen in e-court application. Application of e-litigation is to support the litigation process to send the documents needed, included reply and conclusion from each party until the judge's verdict electronically.

${ }^{18}$ Sudarsono, "Konsep Peradilan Secara Elektronik Di Lingkugan Peradilan Tata Usaha Negara," Tanjungpura Law Journal 3, no. 1 (2019): 42-64. 
As stated in Article Number 15 of Perma, that e-summons goes to plaintiff and defendant which agreed to be informed electronically, while this regulation is exceptional for administrative court, it means defendant's approval not required. Article Number 20 of Perma, stated that after mediation process failed, both parties gives approval to the next step is e-litigation. When mediation is not an obligation for both parties, the approval of plaintiff already given when registered, and in administrative dispute the defendant's approval is not required. Based on Article number 20 of Perma, for administrative disputes will directly to court room after judges definite the date. There is no mediation required in Court, since administrative disputes are disputes arise in administrative law as public law. This regulation can't match to the settlement of administrative disputes as regulates in Act Number 5 Year 1986 of Administrative Court. In this article, we can give legal systematic interpretation since there is no mediation, and then it can go directly to the court room.

The importance of regulations are lie inside the legal system, to interpretation regulations by connecting with relevance or the whole legal system is called legal systematic interpretation. The whole legal system means the Administrative Court's system, started from put the lawsuit into the Court until the execution of judge's verdict. If there is no definite regulation, then it will follow the administrative court's system automatically. To analyze the legal gap in article 20 of Perma and Act Number 5 Year 1986 of Administrative Court, it will use the legal systematic interpretation. Implementation of e-court in Court has to consider some important points of procedure in process. Based on Act Number 5 Year 1986 of Administrative Court, there are two processes begin with dismissal process (Article Number 62) and preparatory examination (Article 63), before enter to the court room. Dismissal process handled by Chief of Court aimed to prepare examination before case goes to preparatory examination. Preparatory examination is a special process in Court because aimed to equalizing position between plaintiff and defendant, as an implementation of dominus litis principle. These 2 (two) process not regulated in Perma, whereas both are important process in a whole system of Court. Since there is no definite regulation implementation of dismissal process and preparatory examination electronically, we use legal systematic interpretation since the 2 (two) process are important in administrative procedural law and cannot be abandon, it is wise to follow the regulations as regulated in Article Number 62 and 63 of Act Number 5 Year 1986 of Administrative Court, instead of follow the regulation in Perma. This is also the implementation of lex specialis derogat lex generalis, the special regulations put aside the general regulations.

Article 23 of Perma stated that, third party may join asked for application in e-litigation, but when their refuse to follow the e-court as obliged in Article number 23 of Perma, Judge will give establishment that the application is not acceptable. If the third party asked for approval, he or she already know the legal consequence, and will 
take any risk to defend the civil rights legally, and then it is unreasonable to refuse the e-court. Unless he or she withdrawal the application for some reasons, the judge will give establishment of these.

After both process completed, judge will decide the date for e-litigation, and both parties should prepare the documents. Based on approval from both parties, evidentiary process for witness and witness expert can be held using audio visual communication, so all parties are participated (vide Article Number 24 of Perma). The written evidence should be checked directly by Judges, parties, it is to keep the principle of judiciary, such as transparency and accountability. The evidentiary procedure still based on the regulations as regulated in Article number 25, it means that based for each Court there are different rules of evidence and principles. This article shows that there are confuse regulations when it comes to evidentiary process, especially regulations Article number 24 and 25.

Article number 24 regulates if agreed by parties, hearing of witness or expert witness can be done through audio visual communication so everyone can participate. This phrase can cause a legal systematic interpretation: if there is no deal within parties, then the hearing cannot be done through audio visual communication, and should be in the court room. It shows that hearing witness can be done by audio visual or in court room physically, it can be a choice for parties in evidentiary process. Article number 25 stated the evidentiary process based on procedural law, it can be said that procedural law for each are different either the rules of evidence. The evidentiary process is an important part in the whole system of Court, the judges and both parties will check physically the letter of evidence, the witness and witness expert and judge has free to determine the burden of proof, strength of proof, the evidence use in the court room. The evidentiary process through audio visual is different compare to physically process, especially to implement the principles of independence of judiciary. While Article number 24 does not regulate about the letter of evidence, only regulate about witness and witness expert to testify through audio visual. The use of electronic evidence is allow in the court room due to IT's development, prior to preserve principle of independence of judiciary. Evidenciary process implement the dominus litis principle, it means that judge has to become more active to find out the materiele truth, besides the principle of free proff restricted. Those two principles are blend to give justice and to equalize the position between Plaintiff and Defendant, as both are special principles to support the Court's system.

Refer to theory of system of law by Lawrence Friedman, there are substance, structure and culture which has influence and important to build e-court as new way to proceed. Structure of law consist of court, the court's administration, organization has to arrange quite good, including the network, system of technology and other infrastructures. Strengthening institution to provide access to justice is the one goals 
of sustainable development goals (SDG's), besides build effective, accountable and inclusive institutions. People should have easy and quick access to the court, from conventional type until modern type using the internet. Government has to provide the good quality of infrastructures as hard skill, and improve the ability as soft skill to all the section of judiciary system without exception. Socialization of e-court must be implemented by the government using all types of communication, hopefully people will understand the new way to proceed in the court. Substance of law are the substance of regulations which has to be clear, no bias, no contradiction with other regulations. If there is contradiction it means there is no harmonization and synchronization, it can cause legal certainty for justice seekers. Culture has immense influence because it change the habit and mind set of how to proceed in the court. For many years, people used to come to the court to defend their rights, and enter into court room to give evidences. The transition needs time and good socialization from government, while it can not change immediately. E-court is change the court administration, proceeding in the court room using the information technology.

The Supreme Court has tried to regulate and implement the procedural of law from based on paper becomes paperless using the IT, even though there are still some process cannot transform electronically and still using the main procedural of law for each disputes or cases. This paradigm shifting in procedural of law, also give impact to all actors in judiciary process, without no exception. The ability and competence to use IT is highly needed, and people are force to learn how to use for their individual capability. To keep the independence of judiciary, fair play, the hearing of witness should be heard in the court room. This is show that implementation of e-litigation may not fully electronically, when it comes for some judiciary purpose, and put the interest of parties as priority. The implementation of e-court in Court can be said is mix process between the development of technology and the regulations, but still put the principles of judiciary as a prior to give justice, or a hybrid system is being implement in Indonesia. Not all the process able to transform into technology, though there should be a way to embody the aim.

It needs lawyers who can follow the e-court, they should have ability, an open mind thinking of information technology that challenge the principles, rules and concept of law and develop into new legal hermeneutics approaches, to shifting from text driven law become computer driven law or artificial legal intelligence, that needs collaboration action from interdisciplinary. ${ }^{19}$ Every legal scholar has to understand this development, while it also needs different approaches to shift from the previous paradigm to modern technology without disregard important principles, even though to modified into friendly understanding.

\footnotetext{
${ }^{19}$ Peggy Valcke, Inge Graef, and Damian Clifford, "IFairness - Constructing Fairness in IT ( and Other Areas of ) Law through Intra- and Interdisciplinarity" 34 (2018): 707-14, https://doi.org/10.1016/j.clsr.2018.06.010. accessed on 5 August 2020
} 
The concept of e-court has 2 (two) meanings, first as building of court, but paperless, second virtual court there is no building, but judges, lawyers, parties will meet and discuss the disputes, and send the documents through video conference, electronic documents, digital signature via internet. For comparison, in U.K., virtual court which developed is hybrid type of total paperless court and conceptualized virtual court, since it is not able for criminal courts, maybe possible for commercial transactions and arbitrary process $^{20}$. The difference of hybrid type in Indonesia's judiciary system are, still use physical attendance for witness and expert witness based on regulations. The hybrid type for each country may differ based on system of law, politics, and culture.

Refer to research result by M. Beni Kurniawan, to become a good e-court there should be new rules regarding the electronic court, the human resources to support the information and technology of judiciary system, the scrutiny and authentication of data, the complete and comprehensive information to society to encourage using the e-court application, a proper budget to build the infrastructure and proper facilities ${ }^{21}$. He also compared with e-court in Singapore, there were some issues could not avoid, i.e. about the large budget, lack of human resources, the amount of cases comes to court, and the security and authentication of data.

Based on research result in Brazilian judiciary, there are some factors influenced the judiciary systems, such as legislations, numbers of cases for appeals, judges and judicial administrators are also impacted from the other sector and constrained by the judiciary system and litigants ${ }^{22}$. This could be the same conditions in some countries, which has to meet with the interest of societies. There are some important points to consider such as politics, law, and culture society to bring the judiciary system become modern and more useful for everyone.

\section{E-Court Towards Digitalization and E- government}

${ }^{20}$ Setlur B N Prakash, "E Judiciary : A Step towards Modernization in Indian Legal System," Journal of Education \& Social Policy 1, no. 1 (2014): 111-24.

${ }^{21} \mathrm{M}$ Beni Kurniawan, "IMPLEMENTATION OF ELECTRONIC TRIAL ( E- LITIGATION ) ON THE CIVIL CASES IN INDONESIA COURT AS A LEGAL RENEWAL OF CIVIL," Jurnal Hukum Dan Peradilan 9, no. 1 (2020): 43-70, https://doi.org/10.25216/JHP.9.1.2020.43-70. accessed on 7 August 2020

${ }_{22}$ Mario Procopiuck, "Information Technology and Time of Judgment in Specialized Courts : What Is the Impact of Changing from Physical to Electronic Processing?," Government Information Quarterly 35, no. 3 (2018): 491-501, https://doi.org/10.1016/j.giq.2018.03.005.157 tax enforcement cases filed by public and private organizations in the traditional manner and in a fully electronic system in an attempt to clarify some of the reasons for congestion, because the stakes are high: in Brazil approximately US\$ 415.1 billion pertaining to the federal government are disputed in 3.6 million of these cases. No significant difference was found between the duration of physical and electronic cases, and physical cases are occasionally swifter than electronic cases; consequently, the solutions to this congestion will depend on actions by the legal system, managers and judges, and litigant strategies. 1.","author":[\{ “dropping-particle":",,"family":"Procopiuck","given":"Mario","non-dropping-particle":"”,",parse-names":false,"suffix":"”\}],"container-title":"Government Information Quarterly","id":"ITEM-1","issue":"3","issued":\{“da te-parts":[[“2018”]]\},"page":"491-501","publisher":"Elsevier","title":"Information technology and time of judgment in specialized courts : What is the impact of changing from physical to electronic processing ?","type":"article-journal","volume":"35"\},"uris":["http://www.mendeley.com/documents/?uuid = 5a89958e-af75-4844-97ef8d13c740a901","http://www.mendeley.com/documents/?uuid = 7e8a7d41-7436-4ba0-ad73-23c47c36a4c6"]\}]," mendeley": ‘ “formattedCitation":"Mario Procopiuck, "Information Technology and Time of Judgment in Specialized Courts : What Is the Impact of Changing from Physical to Electronic Processing ?," < i > Government Information Quarterly </i > 35, no. 3 (2018 accessed on 10 September 2020 
Internet of Things (IoT) is an innovative concept of the internet, which was initially introduced by Kelvin Ashton in 1999. ${ }^{23}$ Elham Ali Shammar and Ammar Thabit Zahary stated: the evolution of IoT can be illustrated through several stages as shown in Figure $1 .^{24}$ They also said that internet has changed radically in the way people interact in the virtual world, in their careers or social relationships. IoT technology has added a new vision to this process by enabling connections between smart objects and humans, and also between smart objects themselves, which leads to anything, anytime, anywhere, and any media communications. ${ }^{25}$

Figure 1. The evolution of IoT

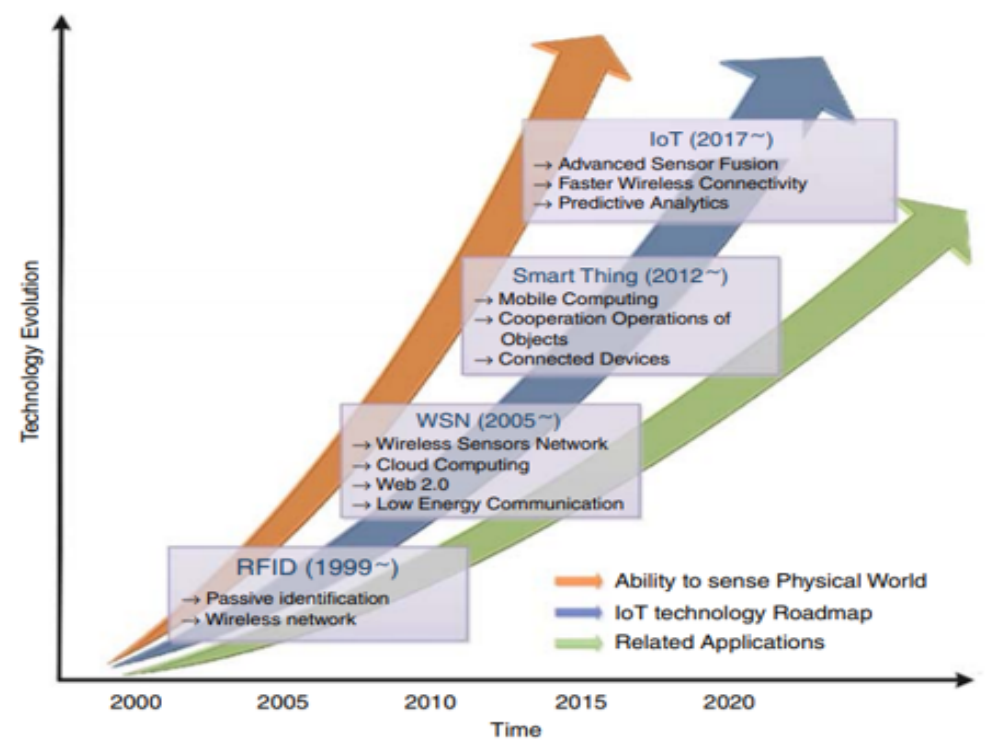

Source: (E. Shammar \& A. Zahary, 2019)

Internet of Things (IoT) becomes important since the uses of internet in broaden the pathways, and there is no definite meaning of IoT but the benefit flows in the social and politics, which had significant role and offer a smart or intelligent government, and admit as a source of growth and innovation in government's activity. ${ }^{26}$ The use of IoT become unavoidable into our life which utilized from all sector to increase the quality of product in industrial processing, and government to make good quality of public service.

The changes of politics, societies, and development of information technology (IT) gives impact to governance administration to shift from old paradigm to new paradigm

\footnotetext{
${ }^{23}$ Yaser Gamil et al., "Internet of Things in Construction Industry Revolution 4.0: Recent Trends and Challenges in the Malaysian Context," Journal of Engineering, Design and Technology, 2020, https://doi.org/10.1108/JEDT-062019-0164. accessed on 11 September 2020

${ }^{24}$ Elham Ali Shammar and Ammar Thabit Zahary, "The Internet of Things (IoT): A Survey of Techniques, Operating Systems, and Trends," Library Hi Tech 38, no. 1 (2019): 5-66, https://doi.org/10.1108/LHT-12-2018-0200. 11 September 2020

${ }^{25}$ Shammar and Zahary.

${ }^{26}$ Bernd W Wirtz, Jan C Weyerer, and Franziska T Schichtel, "An Integrative Public IoT Framework for Smart Government," Government Information Quarterly 36, no. 2 (2019): 333-45, https://doi.org/10.1016/j.giq.2018.07.001. 11 September 2020
} 
based on information technologies to escalate the public service and to enlarge the participation of society to build the nations. It needs a comprehensive policy to manage, also build the culture of the people in all sectors accustomed to the use of modern technologies in their daily routines to approach the government. The development of IT will not give prosperous to society if does not come with appropriate regulations, culture and good public services.

There is no definite meaning of e-government, but we can see from other countries when they are trying to build, implement the regulations of e-government. E-government is sometimes referred to as the second revolution in public management after NPM and according to the The Economist it will transform not only the way in which most public services are delivered, but also the fundamental relationship between government and citizen. ${ }^{27}$ Broadly, e-government involves the use of Internet-based technologies to transact the business of government. ${ }^{28}$

Based on Lawrence Friedman's system of law theory, there are 3 (three) points to explain. Starting from the legal structure (structure of law), legislative makes a plan of regulations and implementations for them. Legal structure is called a structural system that determines whether or not the law is implemented properly. The budget to build the infrastructure also has to think carefully, because it is need a huge budget, in order to reach the goals. Legal substance (substance of the law) should be citizen friendly, easy to implement, should be use the easy command and regulations. The substance of the law is a substantial system that determines whether or not the law can be implemented. The substance of law also includes living law, not just the rules in the law books. Legal culture (culture of law) is a human attitude towards law and the legal system-beliefs, values, thoughts, and expectations Culture of law is needed to change the society's perspective about: how to get closer, interactive with government official and / or agency in the modern government using IT.

Digitalization is very important because human findings will inevitably have an impact on changes in social relations. Social relations are changing for those who want to enter the era of development, especially digitalization. Digitalization is needed to speed up decision making. In a new era, it must be realized that this can create a clash of cultures or clash of civilization.

As welfare state, the role of government is vary such as education, health, housing, land-owned, birth and other socials matters. The use of IT has to starts in an easy methods so everyone also easy to learn and use for daily routines. It is challenge to change the habits, paradigms of how to live based on paper become to use of IT and paperless for government's matter. In fact, it is need a struggle and effort to change this habits and paradigm, since some people are less of knowledge in using IT. The

\footnotetext{
${ }^{27}$ Gamil et al., "Internet of Things in Construction Industry Revolution 4.0: Recent Trends and Challenges in the Malaysian Context."

${ }^{28}$ Gamil, et al.
} 
government has to moving forward in using IT and change paradigm of government's public service and management.

Implementation of e-government in Indonesia has begun since several years, some regulations and IT's infrastructures built to support the regulations. The concept of e-government may vary in some countries, and so does the implementation between develop and modern countries. The success of e-government has to come from the society's perspectives, values, then regulations and cultures. ${ }^{29}$ The relations factors each has different perspectives so it becomes difficult to combine in order to build a good e-government.

E-court is not a matter of being ready or not and is also not an option but already is a consequence. Technology will continue to move, then there is no other choice but to master and to controll technology properly and correctly in order to provide the greatest benefit. Court as judicial institutions in Indonesia must respond to the development of the digital world, to produce decisions that are fair and beneficial to society.

\section{CONCLUSION}

Implementation e-court for Court cannot purely use IT, since there are differences conditions. First, there is no regulation of implementation for dismissal process and preparatory examination, in Perma the 2 (two) important process i.e. dismissal process and preparatory examination, before enter the court room, there is no regulation of implementation for both process in Perma. Second, there is inconsistency between Article number 24 and 25 of Perma, for evidentiary process follows regulations for each procedural system; it means that for Court follows the Act Number 5 Year 1986 of Administrative Court. Third, the legal gap and legal interpretation in Perma cause legal certainty in implementation of e-court especially in Administrative Court.

Government has to support the use of IT for public services, which will give benefit, efficiency to all parties. Development of IT cannot be denied, while people have to accept and increase the ability to learn and use of IT. Some factors are influence the implementation of IT such as behavior, culture and regulations, but this condition has to adjust to the development.

\section{REFERENCES}

\section{Books}

Machmud, Syahrul, (2012). PENEGAKAN HUKUM LINGKUNGAN INDONESIA; Penegakan Hukum Administrasi, Hukum Perdata, Dan Hukum Pidana Menurut Undang-Undang No. 32 Tahun 2009, GRAHA ILMU, Yogyakarta

Maftuh Effendi, (2017), Dinamika Yurisdiksi Peradilan Administrasi, Pusaka Media,

\footnotetext{
${ }^{29}$ Jean Damascene Twizeyimana and Annika Andersson, "The Public Value of E-Government - A Literature Review," Government Information Quarterly 36, no. 2 (2019): 167-78, https://doi.org/10.1016/j.giq.2019.01.001. 11 September 2020
} 
Jakarta.

Nasution, Bahder Johan, (2018), Metode Penelitian Ilmu Hukum, Mandar Maju, Bandung.

Marzuki, Peter Mahmud, 2007, Penelitian Hukum, Kencana, Jakarta.

Sudarsono, (2019), "Penerapan Peradilan Elektronik Di Lingkungan Peradilan Tata Usaha Negara" In Legal Issues Pada Peradilan Tata Usaha Negara PascaReformasi Hukum Acara Dan Peradilan Elektronik, Kencana, Jakarta.

Suteki dan Galang Taufani, (2018), Metodologi Penelitian Hukum (Filsafat, Teori, Dan Praktik), RajaGrafindo Persada, Depok.

Yuswalina, (2019), HUKUM ADMINISTRASI NEGARA, Setara Press, Malang.

Journal and other scientific reference

Bo’a, Fais Yonas. (2018), Pancasila Sebagai Sumber Hukum Dalam Sistem Hukum Nasional. Jurnal Konstitusi 15, no. 1,p. 27-49. https://doi.org/10.31078/jk1512.

Bunga, Marten. (2018), Usaha Negara Dalam Menyelesaikan Sengketa Tanah. Gorontalo Law Review 1, no. 1, p. 39-49.

Canestrino, Rossella, Marek $\square$ wiklicki, Piotr Kafel, Magdalena Wojnarowska, and Pierpaolo Magliocca. (2020), "The Digitalization in EMAS-Registered Organizations: Evidences from Italy and Poland." TQM Journal, https://doi. org/10.1108/TQM-12-2019-0301.

Chen, Yu-che, Lung-teng Hu, Kuan-chiu Tseng, Wen-jong Juang, and Chih-kai Chang. (2019), Cross-Boundary e-Government Systems : Determinants of Performance ๑. Government Information Quarterly 36, no. 3, p.449-59. https://doi. org/10.1016/j.giq.2019.02.001.

Gamil, Yaser, Majid A. Abdullah, Ismail Abd Rahman, and Muhammad Mujtaba Asad. (2020), Internet of Things in Construction Industry Revolution 4.0: Recent Trends and Challenges in the Malaysian Context. Journal of Engineering, Design and Technology, https://doi.org/10.1108/JEDT-06-2019-0164.

Habibi, Dani. (2019), Perbandingan Hukum Peradilan Tata Usaha Negara Dan Verwaltungsrecht Sebagai Perlindungan Hukum Rakyat. Kanun Jurnal Ilmu Hukum 21, no. 1,p. 1-22.

Hendrik Salmon. (2020), "EKSISTENSI PERADILAN TATA USAHA NEGARA (PTUN) DALAM MEWUJUDKAN SUATU PEMERINTAHAN YANG BAIK Oleh : Hendrik Salmon." Jurnal Sasi 16, no. 4, p. 16-26.

Kurniawan, M Beni. (2020), IMPLEMENTATION OF ELECTRONIC TRIAL ( ELITIGATION ) ON THE CIVIL CASES IN INDONESIA COURT AS A LEGAL RENEWAL OF CIVIL. Jurnal Hukum Dan Peradilan 9, no. 1, p. 43-70. https:// doi.org/10.25216/JHP.9.1.2020.43-70.

Martin Krygier. (2015), Rule of Law (and Rechtsstaat). International Encyclopedia of the Social \& Behavioral Sciences (Second Edition) March, p. 78-787. https://doi.org/ https://doi.org/10.1016/B978-0-08-097086-8.86105-X.

Nursobah, Asep. (2015), "Pemanfaatan Teknologi Informasi Untuk Mendorong Percepatan Penyelesaian Perkara Di Mahkamah Agung." Jurnal Hukum Dan Peradilan 4, no. 2,p. 323-34. 
Pattnaik, Pinaki Nandan, Satyendra C. Pandey, and Mahendra Kumar Shukla. (2018), Mapping Critical Success Factors in Efficient Court Management: Two Case Studies from India. International Journal of Law and Management 60, no. 2, p.717-29. https://doi.org/10.1108/IJLMA-03-2017-0023.

Phahlevy, Rifqy Ridlo, et.al. (2019), "Pergeseran Paradigma Peradilan Tata Usaha Negara Di Indonesia Dan Belanda." Arena Hukum 12, no. 3, p. 576-91.

Prakash, Setlur B N. (2014), E Judiciary : A Step towards Modernization in Indian Legal System. Journal of Education \& Social Policy 1, no. 1, p. 111-24.

Procopiuck, Mario. (2018), Information Technology and Time of Judgment in Specialized Courts : What Is the Impact of Changing from Physical to Electronic Processing ? Government Information Quarterly 35, no. 3, p. 491-501. https:// doi.org/10.1016/j.giq.2018.03.005.

Putrijanti, Aju, and Kadek Cahya Susila Wibawa. (2020), The Role of Administrative Courtin Reinforcing the Good Governance. Test Engineering and Management 83, no. March-April p. 18483-89. http://testmagzine.biz/index.php/testmagzine/ article/view/6980/5388.

Re, Richard M, and Alicia Solow-niederman. (2019), Developing Artificially Intelligent Justice. Stanford Technology Law Reviewd Technology Law Review 22, no. 8, p. 242-89.

Schäfke-zell, Werner, and Ida Helene Asmussen. (2019), The Legal Profession in the Age of Digitalisation An Outline of Three Potential Transformations in Legal Education. Utrecht Law Review 15, p. 65-79.

Shammar, Elham Ali, and Ammar Thabit Zahary. (2019), "The Internet of Things (IoT): A Survey of Techniques, Operating Systems, and Trends." Library Hi Tech 38, no. 1 (2019): 5-66. https://doi.org/10.1108/LHT-12-2018-0200.

Sudarsono. (2019), Konsep Peradilan Secara Elektronik Di Lingkugan Peradilan Tata Usaha Negara. Tanjungpura Law Journal 3, no. 1, p. 42-64.

Tonn, Bruce, Dorian Stiefel, John M Scheb, Colin Glennon, and Hemant Kumar. (2012), Future of the Courts: Fixed, Flexible, and Improvisational Frameworks. Futures 44, no. 9,p. 802-11. https://doi.org/10.1016/j.futures.2012.07.005.

Twizeyimana, Jean Damascene, and Annika Andersson. (2019), The Public Value of E-Government - A Literature Review. Government Information Quarterly 36, no. 2,p. 167-78. https://doi.org/10.1016/j.giq.2019.01.001.

Valcke, Peggy, Inge Graef, and Damian Clifford. (2018), IFairness - Constructing Fairness in IT ( and Other Areas of ) Law through Intra- and Interdisciplinarity, 34,p. 707-14. https://doi.org/10.1016/j.clsr.2018.06.010.

Wibawa, Kadek Cahya Susila, and Sri Nurhari Susanto. (2020), Establishing a Special Autonomy Model in Bali as a Means of Preserving Hindu Balinese Culture and Space. International Journal of Scientific and Technology Research 9, no. 4, 1609-14. http://www.ijstr.org/final-print/apr2020/Establishing-A-SpecialAutonomy-Model-In-Bali-As-A-Means-Of-Preserving-Hindu-Balinese-CultureAnd-Space.pdf.

Wirtz, Bernd W, Jan C Weyerer, and Franziska T Schichtel. (2019), An Integrative Public 
IoT Framework for Smart Government. Government Information Quarterly 36, no. 2, p. 333-45. https://doi.org/10.1016/j.giq.2018.07.001.

\section{Regulations}

The 1945 Constitution of the Republic of Indonesia.

Act No 5 Year 1986 of Administrative Court jis Act Number 9 Year 2004 and Act Number 51 Year 2009.

Act Number 30 Year 2014 of Governance Administration.

Supreme Court Regulation (Perma) Number 3 Year 2018 concerning Electronic Case Administration.

Supreme Court Regulation (Perma) Number 1 Year 2019 of Case Administration and Court Electronically. 